insistence on the scientific discoveries will make it forbidding to the layman.

Eddington's life was outwardly uneventful. $\mathrm{He}$ was born in 1882 . He was still an infant when his father died, and his early years were spent with his mother and sister at Weston-super-Mare. His amazing precocity was apparent even in his boyhood. Before he was sixteen he went to Owens College, Manchester, and in 1902 he went to Cambridge as a Scholar of 'Trinity. He took the Tripos in his second year, and was Senior Wrangler: never before had this distinction been won by a second-year man. The period from 1906 to 1913 he spent at Greenwich, as chief assistant to the Astronomer Royal. In 1913 he was elected to the Plumian chair at Cambridge, and here he remained until his death in 1944. He was knighted in 1930, and the Order of Merit was conferred on him in 1938. The even tenor of his life was varied by holidays (often in the Lake District with his life-long friend C. J. A. Trimble), excursions abroad to observe eclipses or to attend astronomical congresses, and visits to universities in all parts of the world to lecture on his researches. But if the course of his physical life was comparatively uneventful, his intellectual life was one of high adventure, full of exciting discoveries, and of pioneer voyages "through strange seas of thought alone".

Prof. A. Vibert Douglas, of Queen's University, Kingston, Ontario, the author of this excellent book (which incorporates material contributed by $\mathrm{Mr}$. Trimble), was formerly one of Eddington's research students. The task has clearly been a labour of love. Prof. Douglas has achieved a nice balance between the story of the man and the story of his scientific work. The picture that emerges shows a man rather shy and retiring, but kindly and sympathetic, of immense intellectual power, completely devoted to his research, and with the quiet humour and the fairy-touch of fantasy so evident in his books. The scientific work is described in a way that makes it not too inaccessible to the general reader. Some outstanding points of the story are the early Greenwich work on star-drifts : the impact of Einstein's theory of relativity, of which Eddington was a pioneer exponent: the researches on stellar structure: the exciting moment (in 1920) when the first measurement at Mt. Wilson of the diameter of Betelgeuse verified Eddington's prediction that this star is big enough to hold the Sun and the solar sytem as far out as Mars : the expanding universe : the point at which it became clear that his 'wild idea' about the dwarf stars might after all be possible - that their densities might have incredibly high values, one ton in a cubic inch : the long controversy with Jeans about radiative equilibrium : the final bold speculations about fundamental theory, left still incomplete at his death.

Eddington's life was a peculiarly happy and satisfying one. He had the felicity, denied to many men, of being able to lead just the kind of life he most desired, and to achieve just the kind of things he hoped to achieve. We can justly apply to him Maurice Baring's tribute to a hero in a different sphere:

"Here is no waste,

No burning Might-have-been,

No bitter after-taste,

None to censure, none to screen,

Nothing awry, nor anything misspent;

Only content, content beyond content,

Which hath not any room for betterment".

L. A. PARS

\section{A FESTSCHRIFT FOR GORDON CHILDE}

Contributions to Prehistoric Archæology

Offered to Professor V. Gordon Childe in Honour of his Sixty-fifth Birthday. By Twenty-seven authors. (Proceedings of the Prehistoric Society for 1955, New Series, Vol. 21.) Edited by Prof. J. G. D. Clark, assisted by Dr. K. P. Oakley and Prof. S. Piggott. Pp. vi $+315+30$ plates. (Gloucester: The Prehistoric Society, c/o John Bellows, Ltd., Eastgate, 1956.) $42 s$.

7 HE Proceedings of the Prehistoric Society, Now Series, 21, 1955, consist of articles by twenty. seven authors offered to Prof. V. Gordon Childe in honour of his sixty-fifth birthday. There is a characteristic portrait of Gordon Childe as the frontispiece. Prof. Childe is Australian by birth and was at Oxford at the time of the First World War. After going down from the university he travelled widely in Central and Eastern Europe. Later, for a short time, he was the librarian for the Royal Anthropological Institute, but on the founding of the Abercromby chair of archæology at the University of Edinburgh he became its first holder. While at Edinburgh he published extensively on archæological matters and completed some first-class excavations, as, for example, the 'dig' at Skara Brae in Orkney. On leaving Edinburgh he became professor of prehistoric European archæology in the University of London and director of the Institute of Archrology in Regent's Park.

The articles are by a number of distinguished savants, of various nationalities, and the subjects treated range in time from the lower palæolithic to the late Iron Age. It is obviously impossible in a short review even to mention all the various articles, and the citing of one or two does not mean that others are not equally important. Prof. J. G. D. Clark's article on a microlithic industry from the Cambridgeshire Fenland is an important contribution to knowledge, and Dr. D. A. E. Garrod's illustrated article on palæolithic spear-throwers makes interesting reading. Coming to later times, an article by $\mathrm{A}$. Bryusov on neolithic dwellings in the forest zone of the European part of the U.S.S.R., though all too short, is of great interest, as it is not too easy to get information from behind the Iron Curtain. Another interesting article is by T. Sulimirski on Thuringian amphore, and J. Banner from Budapest describes the researches on the Hungarian Bronze Age since 1936 and the Bronze Age settlement at Békés-Várdomb. A well-illustrated account of a Bronze Age house at Poliokhni (Lemnos) by Luigi Bernabò Brea of the Syracuse Museum must be mentioned, as, too, must a description of a doctor's grave of the Middle La Tène Period in Bavaria by J. M. de Navarro. The volume concludes with an account of the pins and the chronology of brochs by R. B. K. Stevenson, and a bibliography of Childe's publications compiled by Isobel $\mathrm{F}$. Smith.

The editor is to be congratulated on making this festschrift one of the numbers of the Proceedings of the Prehistoric Society and not attempting to publish a separate volume. The existence of the latter would soon be forgotten and in consequence the articles would be comparatively unknown. By consecrating a number of the Proceedings the important articles which appear will be accessible and therefore of permanent use to students. M. C. BURKrrr 